\title{
Hepatitis B Virus Genotype D Predominates HBsAg-Positive Egyptian Blood Donors and Is Mainly Associated with a Negative HBeAg Serostatus
}

\author{
Febee E. Habil ${ }^{a, b}$ Wafaa K.M. Mahdi ${ }^{b}$ Sayed F. Abdelwahab ${ }^{b}$ \\ Mohamed Abdel-Hamid ${ }^{b}$ \\ ${ }^{a}$ Minia Regional Blood Bank, and ${ }^{\mathrm{b}}$ Department of Microbiology and Immunology, Faculty of Medicine, \\ Minia University, Minia, Egypt
}

\section{Key Words}

Blood donors - ELISA - Genotyping · Hepatitis B virus .

$\mathrm{HBsAg} \cdot \mathrm{HBeAg} \cdot \mathrm{PCR} \cdot$ Restriction fragment length

polymorphism

\begin{abstract}
Objectives: Hepatitis B virus (HBV) infection is a global health burden. In this regard, Egypt has an intermediate HBV seroprevalence. HBV is classified into ten different genotypes (AJ) with different geographic distributions. Genotype $D$ is the most prevalent in the Middle East. Limited data are available about HBV genotyping among Egyptian blood donors, particularly in Upper Egypt. We examined the seroprevalence of HBV among 12,000 blood donors attending the blood transfusion services center in Minia Governorate, Upper Egypt. Methods: $\mathrm{HBsAg}$ and HBeAg were examined by ELISA while HBV-DNA was examined by PCR. HBV genotyping was conducted by restriction fragment length polymorphism. $\boldsymbol{R e}$ sults: $\mathrm{HBsAg}$ was detected in 237 donors (1.98\%). The HBVDNA of 50 donors with the highest HBsAg OD was examined for the HBV genotype. All 50 DNA-positive samples were of genotype D. $82 \%$ of the DNA-positive donors were males, coinciding with their representation in the cohort. ALT levels were normal in $88 \%$ of genotyped subjects, while $84 \%$ of
\end{abstract}

them were HBeAg negative. Conclusion: Taken together, these data indicate that HBV genotype $D$ is the predominant genotype among HBsAg-positive blood donors in Upper Egypt and was in $>80 \%$ of the subjects associated with a negative $\mathrm{HBeAg}$ serostatus.

Copyright $\odot 2013$ S. Karger AG, Basel

\section{Introduction}

Hepatitis B virus (HBV) infection is a global health problem with more than 350 million people who are chronic carriers of the virus [1]. Ten HBV genotypes (labeled A-J) are currently recognized [2]. These ten HBV genotypes have unique genomic insertions and deletions, resulting in differences in genomic length [3]. In addition, subgenotypes have been described that differ by at least 4\% [4]. Different HBV genotypes have different geographic distributions. In this regard, genotype A is predominant in Northwestern Europe and North America while genotypes B and C are observed mainly in Asia. The Mediterranean region has genotype $\mathrm{D}$ as the most prevalent type. Genotype $\mathrm{E}$ is localized mainly in East, Central and West Africa [5]. Genotype F is found mainly in South and Central America [6], while genotype $G$ has been

\section{KARGER}

E-Mail karger@karger.com

www.karger.com/int
(C) 2013 S. Karger AG, Basel

0300-5526/13/0565-0278\$38.00/0
Sayed F. Abdelwahab, $\mathrm{PhD}$

Department of Microbiology and Immunology

Faculty of Medicine, Minia University

Minia 61511 (Egypt)

E-Mail sayed.abdelwahab@ med.miniauniv.edu.eg 
found in the USA and France [7]. Genotype $\mathrm{H}$ is found in Central America [8]. Finally, genotype I has been reported in Laos and Vietnam, while genotype J was found in a Japanese patient who lived temporarily in Borneo (reviewed in [2]).

Currently, HBV genotypes can be determined by several methods, including direct sequencing [7], restriction fragment length polymorphism (RFLP) analysis [9], lineprobe assay [10], PCR using genotype-specific primers [11], colorimetric point mutation assay [12], ligase chain reaction assay [13] and ELISA for genotype-specific epitopes [14]. Because HBV genotype classification is based on the entire genomic sequence, sequencing is generally more reliable than serologic subtype nomenclature and is currently used to classify genetic variations in HBV [15].

Egypt has an intermediate (2-7\%) HBV prevalence [16]. The incidence of new HBV infections in Egypt has markedly decreased in children and the general population since the introduction of the HBV vaccine into the expanded program of immunization for children in 1992 and its availability for adults $[17,18]$. The decline in HBV incidence can also be attributed to the implementation of routine blood donor screening programs. However, HBV infection still poses a significant health burden for adult Egyptians. Few reports have examined the frequency of HBV genotypes in Egypt, and there is very little data about genotyping of $\mathrm{HBV}$-infected blood donors. In one study [19], HBV-DNA was isolated from 105 serum samples from Egyptian patients $(n=51)$ and blood donor carriers of the virus $(n=54)$. HBV genotype $D$ was the predominant genotype detected by sequencing. It was concluded that the D genotype represents the most prevalent HBV genotype in Egypt [19]. The predominance of HBV genotype $\mathrm{D}$ was confirmed in other studies among chronic hepatitis patients [20] and family members of HBVinfected patients [21]. On the other hand, other studies performed in Egypt have demonstrated the simultaneous presence of $\mathrm{HBV}$ genotypes $\mathrm{B}$ and $\mathrm{D}$ among pediatric patients with cancer [22] and also $B$ and $D$, with a few $A$ and $\mathrm{C}$, genotypes among hepatocellular carcinoma adult patients in Cairo [23]. Another study reported that HBV genotype D represented $87 \%$ of $100 \mathrm{HBV}$-DNA-positive patients, including 20 patients with acute hepatitis, 75 patients with chronic active hepatitis and 5 patients with hepatocellular carcinoma; the rest of the subjects (all were acute hepatitis cases) had a mixed D/F genotype [24].

No further reports have investigated the HBV genotype among Egyptian blood donors, particularly in Upper Egypt, which was examined in this study and correlated with HBeAg serostatus.

HBV Genotype D and HBsAg-Positive

Egyptian Blood Donors

\section{Materials and Methods}

Study Subjects and Detection of HBV Infection

This study was conducted on 12,000 volunteer blood donors who presented to the regional blood transfusion services center in Minia Governorate in the period from November 2006 to October 2007. The donors filled out a questionnaire before blood donation and were given a clinical examination and had their clinical history taken. Their age ranged from 16 to 40 years with a mean age of $23.4 \pm 6.58$ years. The subjects were classified as follows: $<20$ years (39\%), 21-30 years (47\%) and 31-40 years (14\%).

Blood was collected in JMS (double or triple) blood bags. Each blood bag was processed for separation of blood components. Blood screening for HBsAg was performed using a Diasorin ELISA test kit (Italy) according to the manufacturer's instructions. Any blood bag that was seropositive for HBsAg by ELISA was subjected to additional laboratory investigations including liver profile (ALT) using a kinetic kit (Biocon Diagnostik, Germany). The normal values of the kit used for measuring ALT levels go up to $41 \mathrm{IU} / 1$ for men and $31 \mathrm{IU} / \mathrm{l}$ for women. HBeAg was also determined by ELISA (Diasorin, Italy).

Detection of HBV-DNA and Determination of HBV Genotype

DNA genotyping was examined after DNA extraction using a mini-kit from Qiagen (Germany). DNA samples were stored at $-20^{\circ}$ until used. The extracted DNA was used to test for HBV-DNA by PCR using $\mathrm{p} 7$ sense primer with the following sequence: $5^{\prime}$-GTG-GTGGAC-TTC-TCT-CAA-TTT-TC- ${ }^{\prime}$, and $\mathrm{p} 8$ antisense primer with the following sequence, $5^{\prime}$-CGG-TA(A/T)-AAA-GGG-ACT-CA(A/C)GAT-3'. In the PCR, $0.75 \mathrm{U}$ Taq polymerase (Roche, Mannheim, Germany) and a nucleotide cocktail was used for PCR amplification after an initial $3 \mathrm{~min}$ of denaturation at $94^{\circ} .40$ cycles of amplification were used in which each cycle was composed of a denaturation step for $45 \mathrm{~s}$ at $94^{\circ}$, annealing for $60 \mathrm{~s}$ at $53^{\circ}$, and extension for $90 \mathrm{~s}$ at $72^{\circ}$ followed by a final extension step for $7 \mathrm{~min}$ at $72^{\circ}$. HBV genotyping was conducted by the RFLP technique and polygenetic analysis of data-base sequences as previously described [25]. Briefly, the RFLP technique was performed using two restriction enzymes in individual reactions. The enzymes used were Tsp5091 (New England Biolabs, Beverly, Mass., USA), which recognizes AATT, and Hinfl (Roche), which recognizes GANTC, where ' $\mathrm{N}$ ' is any nucleotide. The restriction patterns were read visually and compared to standard genotype patterns.

\section{Statistical Analysis:}

All data were entered into a Microsoft Access database (Redmond, Wash., USA). Analysis was done on SPSS package version 17 (SPSS Inc., Chicago, Ill., USA). $\chi^{2}$ tests were performed for categorical data, while Student's t test (or a Mann-Whitney U test when appropriate) was performed for comparisons of continuous data. $\mathrm{p}<0.05$ was considered significant.

\section{Results}

\section{Prevalence of HBV Infection among Egyptian Blood}

Donors in Upper Egypt

Out of the 12,000 blood donors, 237 (1.98\%) subjects were reactive for HBsAg by ELISA. Samples with the 


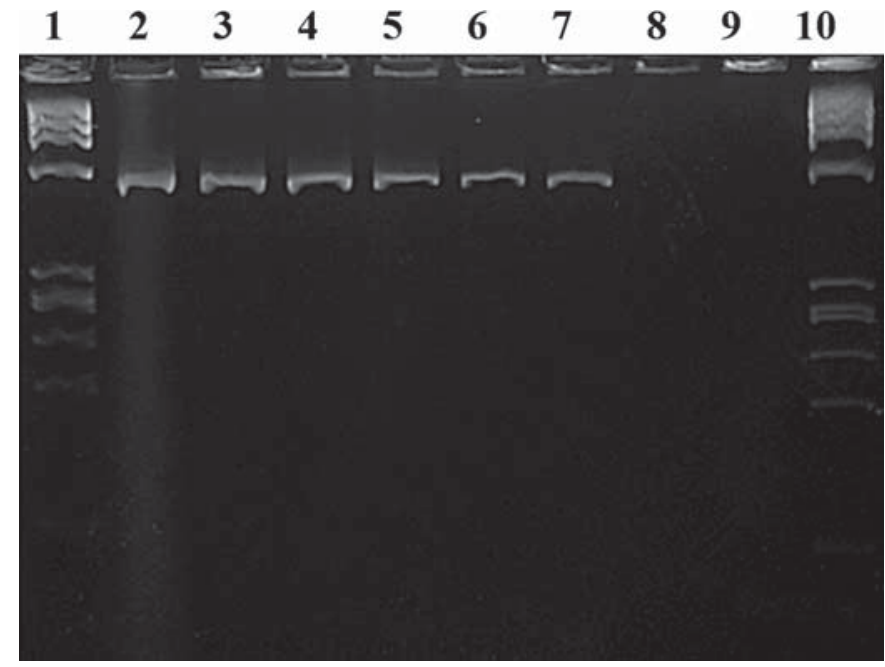

Fig. 1. Detection of HBV-DNA. HBV-DNA was detected by PCR as described in Materials and Methods. A representative experiment is shown. Lanes 1 and 10 are the DNA $\Phi$ X174 ladder, while lanes 2 and 9 are the positive and negative controls, respectively. Lanes 3, 4, 5, 6 and 7 are HBV-DNA positive (giving a specific band or fragment at $541 \mathrm{bp}$ ), while lane 8 is a HBV-DNA-negative sample.

Table 1. Epidemiological and virological characteristics of the selected 62 blood donors to get 50 DNA-positive subjects

\begin{tabular}{llll}
\hline & & $\begin{array}{l}\text { Total examined } \\
(\mathrm{n}=62)\end{array}$ & $\begin{array}{l}\text { DNA + subjects } \\
(\mathrm{n}=50)\end{array}$ \\
\hline Sex & male & $52(84)$ & $41(82)$ \\
& female & $10(16)$ & $9(18)$ \\
\hline Residence & urban & $35(57)$ & $27(54)$ \\
& rural & $27(43)$ & $23(46)$ \\
\hline HBeAg & reactive & $9(14)$ & $8(16)$ \\
& nonreactive & $53(86)$ & $42(84)$ \\
\hline ALT levels & normal & $52(84)$ & $44(88)$ \\
& high & $10(16)$ & $6(12)$ \\
\hline
\end{tabular}

Values are $\mathrm{n}(\%)$.

highest ELISA OD reactive to HBsAg were examined for HBV-DNA by PCR in order to reach a sum of 50 DNApositive subjects for HBV genotyping. An example of the PCR detection of HBV-DNA is shown in figure 1. Of 62 blood donors tested, 12 were HBV-DNA-negative and 50 (81\%) were HBV-DNA-positive by PCR. HBV genotyping was conducted on these $50 \mathrm{HBV}$-DNA-positive blood donors. The demographic and clinical characteristics of the 50 DNA-positive subjects as well as those of the 62 donors screened for HBV-DNA are shown in table 1. As shown, the majority of the DNA-positive donors were males $(82 \%)$, which is very similar to their representation in the 12,000 donors, suggesting no gender bias in HBV infection among these donors. Also, the majority of the 50 DNA-positive subjects were HBeAg-negative (84\%) and $54 \%$ were urban residents. On the other hand, ALT levels ranged from 10 to $77 \mathrm{U} / \mathrm{l}$ with a mean of $23.8 \pm 13.2$, with $88 \%$ of the DNA-positive subjects having normal ALT levels (table 1).

\section{Detection of the HBV-DNA Genotype}

The genotyping study was conducted on the samples of 50 HBV-DNA-positive blood donors using RFLP as described in Materials and Methods. An example of RFLP analysis is shown in figure 2 for 8 subjects, and the analysis revealed that all of the $50 \mathrm{HBV}$-DNA-positive blood donors belonged to HBV genotype ' $D$ ' with patterns 1 , 3 and 4 being the most common subtypes. Correlation between age and ALT levels in genotype D Egyptian blood donors was examined and is presented in figure 3 , which shows that age was inversely proportional to ALT level $\left(\mathrm{R}^{2}=0.03\right)$.

\section{Discussion}

In this study, we screened 12,000 Egyptian blood donors for HBsAg in a regional blood bank in Upper Egypt. We found $237 \mathrm{HBsAg}$-positive cases and screened 62 of them with the highest HBsAg OD to get 50 DNA-positive samples by PCR for genotyping of HBV using RFLP. All 50 DNA-positive samples were of genotype D and $82 \%$ of them were males, coinciding with their representation in the original cohort. ALT levels were normal in $88 \%$ of genotyped subjects, while $84 \%$ of them were $\mathrm{HBeAg}$ negative. Taken together, these data indicate that HBV genotype D is the predominant HBV genotype among HBsAg-positive blood donors in Upper Egypt and is mainly associated with a negative $\mathrm{HBeAg}$ serostatus.

The prevalence of HBV infection in Egypt has been found to be variable in different studies, ranging from 3.2 to $21 \%$, depending on the number of patients and other factors [26, 27]. However, Egypt has been classified as an area of intermediate $(2-7 \%)$ HBV prevalence $[16,28]$. The incidence of new HBV infections in Egypt has markedly decreased in children and the general population since the introduction of the HBV vaccine in $1992[17,18]$ 


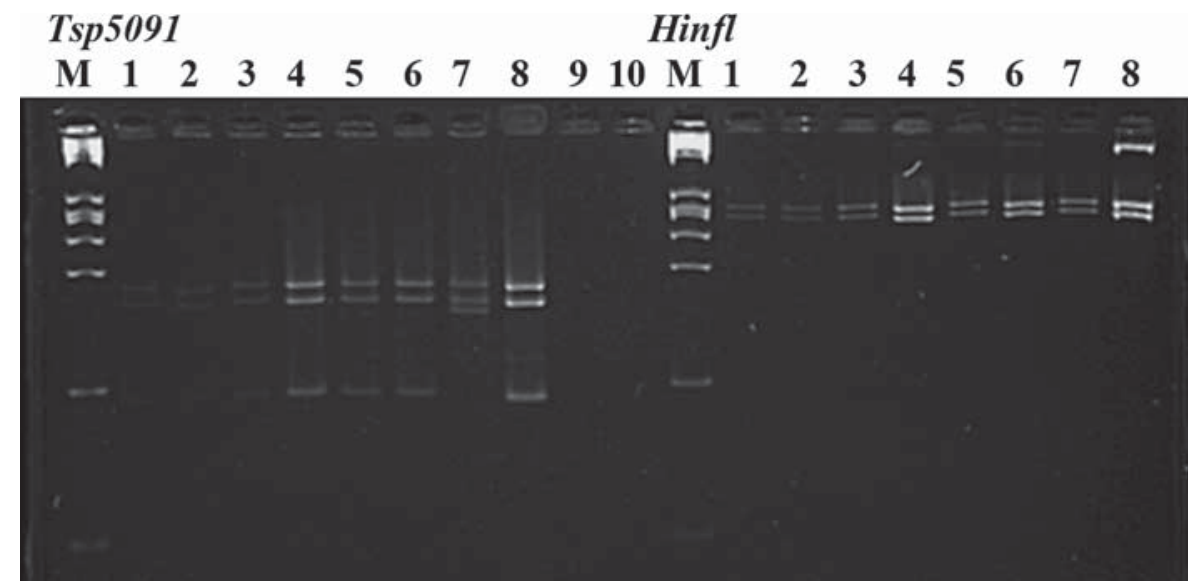

Fig. 2. Genotyping of HBV-DNA using RFLP. Genotyping was carried out by RFLP using restriction enzymes as described in Materials and Methods. Lane M is the $\Phi \mathrm{X} 174$ DNA ladder. The left section of the electrophoresis graph shows Tsp5091 digestion (which recognizes AATT), while the right section shows Hinfl digestion (which recognizes GANTC) of the PCR product. The results were compared with the Tsp5091 and Hinfl patterns of genotype $\mathrm{D}$ according to Lindh et al. [25]. As shown, lanes 1, 2, 3, 4, 5, 6 and 8 (to the left side labeled Tsp5091) shows Tsp5091 restriction patterns that includes 173-and 164-bp double bands which reflect a D1 pattern as indicated in the Tsp5091 reference scheme. On the other hand, lane 7 produced 173-, 164- and 152-bp triple bands, which reflect a D3 pattern as indicated in the Tsp5091 reference scheme (not shown). The Hinfl digestion (right section) shows that lanes 1, 2, 3, 5, 6 and 7 include 274- and 252-bp double bands which reflect genotype D (pattern 3 ) as indicated in the Hinfl reference scheme (not shown). On the other hand, lane 4 produced 252 - and 226-bp bands which reflect genotype D (pattern 4), while lane 8 produced an atypical D pattern. Note: lane 9 and 10 in the Tsp5091 part of the gel are empty wells. and implementation of routine blood screening before transfusion. However, HBV infection still poses a significant health hazard among adult Egyptians particularly because occult HBV is not routinely investigated in the blood banks if the donor is HBsAg negative. The data presented in this study indicate that HBV prevalence (1.98\%) in the 12,000 blood donors tested in Upper Egypt is lower than the reported intermediate prevalence level [16, 28], further supporting the decline in HBV cases.

Genotype D appears to predominate in the Mediterranean basin and the Middle East, which is consistent with Egypt's geographical location in the world [7]. Only 50 samples from 62 ELISA-positive samples with higher OD were found to be HBV-DNA-positive by PCR (81\%), which is higher than a previous report [27]. However, it should be taken into account that some patients are positive for serum HBV-DNA even in the absence of HBsAg. Genotyping revealed that all $50 \mathrm{HBV}$-DNA-positive samples were of genotype D. RFLP was chosen for genotyping of HBV samples in our study as it is a simple method to perform and requires only a PCR prior to its application [3]. Our data are similar to both local and international studies performed on HBV genotypes prevalent in Egypt [19-21] and other Mediterranean and Middle Eastern countries $[29,30]$.

HBV Genotype D and HBsAg-Positive Egyptian Blood Donors

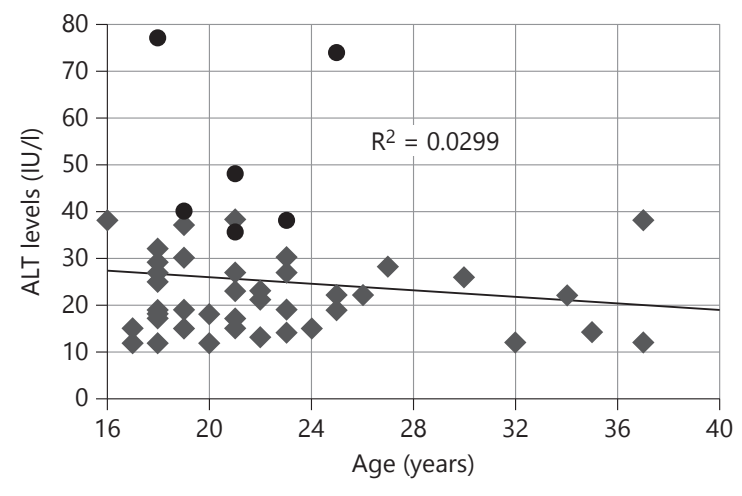

Fig. 3. Correlation between ALT level and age in HBV-DNA-positive genotype D blood donors. As shown, the ALT level was inversely proportional to the age of the subject $(n=50)$. Subjects with ALT levels above normal values ( 3 males and 3 females) are shown as circles while the rest of the 50 subjects are shown as diamonds in the scattergram.

It is well known that HBV genotype could affect the clinical outcome of the infection. In this regard, the commonest presentation in our study was accidental discovery as these blood donors were unaware that they were infected with $\mathrm{HBV}$ until they were found positive for $\mathrm{HBsAg}$ 
during routine screening after blood donation. A similar observation was reported in genotype $\mathrm{D}$ patients, where HBV infection was asymptomatic in approximately 75 $85 \%$ of the subjects $[31,32]$. In contrast to these reports and ours, Thakur et al. [33] found that patients infected with genotype $\mathrm{D}$ strains had more severe chronic liver disease. On the other hand, genotype $\mathrm{D}$ had no influence on the outcome of HBV infection among Indian patients [34].

Demographic characteristics of the 50 donors revealed that $82 \%$ of them were males, a percentage similar to the representation of males in the overall cohort that suggests there is no gender bias in the prevalence of $\mathrm{HBV}$ in these blood donors in Upper Egypt. A similar observation was made in Pakistan [31]. In another study in Turkey, males had a slightly higher rate for HBsAg carriage than females (2.2 in females vs. $2.54 \%$ in males) and the difference was not significant [35]. Our study revealed that $54 \%$ of genotype $\mathrm{D}$ blood donors came from urban areas and the rest were rural residents with no significant difference ( $p>$ 0.05 ), suggesting no role for residence in our settings.

Most of our cases (84\%) had a HbeAg-negative serostatus. The frequent association of precore and basal core promoter mutations with genotype $\mathrm{D}$ may explain the high prevalence of this genotype among chronic HBV patients with a negative $\mathrm{HBeAg}$ phenotype in Western and Mediterranean countries, where genotype D predominates [36] as seen in our study. In our study, only 8 subjects (16\%) were $\mathrm{HBeAg}$ positive, while the rest were HBeAg negative. Several studies lend support to our findings among Egyptian blood donors since these studies show a strong relationship between HBV genotypes and mutations in the precore and core promoter regions that abolish or diminish the production of $\mathrm{HBeAg}[27,30,37]$.
It is known that the core promoter mutants are predominant in Egypt [19]. In Saudi Arabia [30], a lower prevalence of HBeAg was found among the patients with genotype D (28\%), suggesting that $\mathrm{HBeAg}$ clearance occurred at higher rates among patients with genotype D. Also, most of the chronic hepatitis B patients $(78.8 \%)$ were HBeAg negative [27].

The liver profile of our donors revealed that the mean ALT levels were $23.8 \pm 13.6$, with only 6 subjects ( 3 males and 3 females) showing an elevation of ALT level above normal values. Our data showed that ALT level is inversely proportional to the age of the blood donors in Upper Egypt. In this regard, patients with detectable DNA and normal ALT levels are said to be in the immunotolerant phase [38]. In contrast to our study, $65.5 \%$ of the Iranian patients with chronic hepatitis B showed ALT levels that were higher than normal values in Iran [39]. Persistently normal or only slightly elevated ALT levels in blood were a characteristic finding in HBV-DNA-negative samples.

In conclusion, the seroprevalence of HBV among blood donors in Upper Egypt (1.98\%) was lower than the reported intermediate prevalence level $(2-7 \%)$. We found that $\mathrm{HBV}$ genotype $\mathrm{D}$ is the predominant genotype among blood donors attending the regional blood transfusion services center in Minia Governorate. This D genotype was in $>80 \%$ of the subjects associated with a HBeAg-negative serostatus among blood donors in Upper Egypt.

\section{Disclosure Statement}

All authors have no conflicts of interest regarding the work reported in this paper.

\section{References}

1 Lavanchy D: Hepatitis B virus epidemiology, disease burden, treatment, and current and emerging prevention and control measures. J Viral Hepat 2004;11:97-107.

$\checkmark 2$ Kao JH: Molecular epidemiology of hepatitis B virus. Korean J Intern Med 2011;26:255261.

-3 Bartholomeusz A, Schaefer S: Hepatitis B virus genotypes: comparison of genotyping methods. Rev Med Virol 2004;14:3-16.

$>4$ Norder H, Courouce AM, Coursaget P, Echevarria JM, Lee SD, Mushahwar IK, Robertson BH, Locarnini S, Magnius LO: Genetic diversity of hepatitis B virus strains derived worldwide: genotypes, subgenotypes, and HBsAg subtypes. Intervirology 2004;47:289_ 309 .
5 Kidd-Ljunggren K, Miyakawa Y, Kidd AH: Genetic variability in hepatitis B viruses. J Gen Virol 2002;83:1267-1280.

6 Norder H, Courouce AM, Magnius LO: Complete genomes, phylogenetic relatedness, and structural proteins of six strains of the hepatitis B virus, four of which represent two new genotypes. Virology 1994;198:489-503.

7 Stuyver L, De Gendt S, Van Geyt C, Zoulim F, Fried M, Schinazi RF, Rossau R: A new genotype of hepatitis $\mathrm{B}$ virus: complete genome and phylogenetic relatedness. J Gen Virol 2000;81:67-74

-8 Arauz-Ruiz P, Norder H, Robertson BH, Magnius LO: Genotype H: a new Amerindian genotype of hepatitis B virus revealed in Central America. J Gen Virol 2002;83:2059-2073.
-9 Mizokami M, Nakano T, Orito E, Tanaka Y, Sakugawa H, Mukaide M, Robertson $\mathrm{BH}$ : Hepatitis B virus genotype assignment using restriction fragment length polymorphism patterns. FEBS Lett 1999;450:66-71.

10 Grandjacques C, Pradat P, Stuyver L, Chevallier M, Chevallier P, Pichoud C, Maisonnas M, Trepo C, Zoulim F: Rapid detection of genotypes and mutations in the pre-core promoter and the pre-core region of hepatitis $B$ virus genome: correlation with viral persistence and disease severity. J Hepatol 2000;33:430-439.

$>11$ Naito H, Hayashi S, Abe K: Rapid and specific genotyping system for hepatitis B virus corresponding to six major genotypes by PCR using type-specific primers. J Clin Microbiol 2001;39:362-364. 
12 Ballard AL, Boxall EH: Colourimetric point mutation assay: for detection of precore mutants of hepatitis B. J Virol Methods 1997;67: 143-152.

$\checkmark 13$ Minamitani S, Nishiguchi S, Kuroki T, Otani $S$, Monna T: Detection by ligase chain reaction of precore mutant of hepatitis $B$ virus. Hepatology 1997;25:216-222.

- 14 Usuda S, Okamoto H, Iwanari H, Baba K, Tsuda F, Miyakawa Y, Mayumi M: Serological detection of hepatitis B virus genotypes by ELISA with monoclonal antibodies to typespecific epitopes in the preS2-region product. J Virol Methods 1999;80:97-112.

15 Locarnini S, McMillan J, Bartholomeusz A: The hepatitis B virus and common mutants. Semin Liver Dis 2003;23:5-20.

-16 Te HS, Jensen DM: Epidemiology of hepatitis $B$ and $C$ viruses: a global overview. Clin Liver Dis 2010;14:1-21.

$>17$ El Sherbini A, Mohsen SA, Seleem Z, Ghany AA, Moneib A, Abaza AH: Hepatitis B virus among schoolchildren in an endemic area in Egypt over a decade: impact of hepatitis B vaccine. Am J Infect Control 2006;34:600-602.

18 Paez Jimenez A, El-Din NS, El-Hoseiny M, ElDaly M, Abdel-Hamid M, El Aidi S, Sultan Y, El-Sayed N, Mohamed MK, Fontanet A: Community transmission of hepatitis B virus in Egypt: results from a case-control study in Greater Cairo. Int J Epidemiol 2009;38:757765.

19 Saudy N, Sugauchi F, Tanaka Y, Suzuki S, Aal AA, Zaid MA, Agha S, Mizokami M: Genotypes and phylogenetic characterization of hepatitis B and delta viruses in Egypt. J Med Virol 2003;70:529-536.

20 Zaky S, Farghaly AM, Rashed HA, Hassan H, Faouzy E, Makhlouf N, Hussein MR: Clinicopathologic features and genotyping of patients with chronic $\mathrm{HBV}$ infection in the Upper Egypt. Cell Immunol 2010;265:97-104.

-21 Ragheb M, Elkady A, Tanaka Y, Murakami S, Attia FM, Hassan AA, Hassan MF, Shedid MM, Abdel Reheem HB, Khan A, Mizokami M: Multiple intra-familial transmission patterns of hepatitis B virus genotype $D$ in northeastern Egypt. J Med Virol 2012;84:587-595.
22 Zekri AR, Hafez MM, Mohamed NI, Hassan ZK, El-Sayed MH, Khaled MM, Mansour T: Hepatitis B virus (HBV) genotypes in Egyptian pediatric cancer patients with acute and chronic active HBV infection. Virol J 2007; 4:74.

23 Hassan ZK, Hafez MM, Mansor TM, Zekri AR: Occult HBV infection among Egyptian hepatocellular carcinoma patients. Virol J 2011;8:90.

24 Khaled IA, Mahmoud OM, Saleh AF, Bioumie EE: Prevalence of HBV genotypes among Egyptian hepatitis patients. Mol Biol Rep 2011;38:4353-4357.

25 Lindh M, Gonzalez JE, Norkrans G, Horal P: Genotyping of hepatitis B virus by restriction pattern analysis of a pre-S amplicon. J Virol Methods 1998;72:163-174.

26 Tsai NC: Practical management of chronic hepatitis B infection. Semin Liver Dis 2004; 24(suppl 1):71-76.

27 Thakeb F, El-Serafy M, Zakaria S, Monir B, Lashin S, Marzaban R, El-Awady M: Evaluation of liver tissue by polymerase chain reaction for hepatitis B virus in patients with negative viremia. World J Gastroenterol 2005;11: 6853-6857.

28 Poynard T: Hepatitis C and B: Management and Treatment, ed 2. London, Taylor and Francis, 2004.

29 Ayed K, Gorgi Y, Ayed-Jendoubi S, Aouadi H, Sfar I, Najjar T, Ben Abdallah T: Hepatitis B virus genotypes and precore/core-promoter mutations in Tunisian patients with chronic hepatitis B virus infection. J Infection 2007; 54:291-297.

-30 Abdo AA, Al-Jarallah BM, Sanai FM, Hersi AS, Al-Swat K, Azzam NA, Al-Dukhayil M, Al-Maarik A, Al-Faleh FZ: Hepatitis B genotypes: relation to clinical outcome in patients with chronic hepatitis B in Saudi Arabia. World J Gastroenterol 2006;12:7019-7024.
- 31 Baig S, Siddiqui AA, Ahmed W, Qureshi H Arif A: The association of complex liver disorders with HBV genotypes prevalent in Pakistan. Virol J 2007;4:128.

- 32 Kato H, Ruzibakiev R, Yuldasheva N, Hegay T, Kurbanov F, Achundjanov B, Tuichiev L, Usuda S, Ueda R, Mizokami M: Hepatitis B virus genotypes in Uzbekistan and validity of two different systems for genotyping. J Med Virol 2002;67:477-483.

33 Thakur V, Guptan RC, Kazim SN, Malhotra V, Sarin SK: Profile, spectrum and significance of HBV genotypes in chronic liver disease patients in the Indian subcontinent. J Gastroenterol Hepatol 2002;17:165-170.

34 Gandhe SS, Chadha MS, Arankalle VA: Hepatitis $B$ virus genotypes and serotypes in western India: lack of clinical significance. J Med Virol 2003;69:324-330.

- 35 Altindis M, Yilmaz S, Dikengil T, Acemoglu $\mathrm{H}, \mathrm{Hosoglu} \mathrm{S}$ : Seroprevalence and genotyping of hepatitis B, hepatitis C and HIV among healthy population and Turkish soldiers in Northern Cyprus. World J Gastroenterol 2006;12:6792-6796.

36 Fung SK, Wong F, Hussain M, Lok AS: Sustained response after a 2-year course of lamivudine treatment of hepatitis $B$ e antigen-negative chronic hepatitis B. J Viral Hepat 2004; 11:432-438.

37 Orito E, Mizokami M, Sakugawa H, Michitaka K, Ishikawa K, Ichida T, Okanoue T, Yotsuyanagi $\mathrm{H}$, Iino $\mathrm{S}$ : A case-control study for clinical and molecular biological differences between hepatitis B viruses of genotypes B and C. Japan HBV Genotype Research Group. Hepatology 2001;33:218-223.

38 Fattovich G: Natural history and prognosis of hepatitis B. Semin Liver Dis 2003;23:47-58.

39 Mojiri A, Behzad-Behbahani A, Saberifirozi M, Ardabili M, Beheshti M, Rahsaz M, Banihashemi M, Azarpira N, Geramizadeh B, Khadang B, Moaddeb A, Ghaedi M, Heidari T, Torab A, Salah A, Amirzadeh S, Jowkar Z, Mehrabani D, Amini-Bavil-Olyaee S, Dehyadegari MA: Hepatitis B virus genotypes in southwest Iran: molecular, serological and clinical outcomes. World J Gastroenterol 2008;14:1510-1513.
HBV Genotype D and HBsAg-Positive Egyptian Blood Donors
Intervirology 2013;56:278-283 